\title{
WEBINAR DAN WORKSHOP "MEANINGFUL LANGUAGE LEARNING IN DISTANCE LEARNING" PADA PENGAJAR BAHASA INGGRIS
}

\author{
Michael Recard ${ }^{1}$, Atalya Agustin ${ }^{2}$, Neng Priyanti ${ }^{3}$, Meicky Shoreamanis Panggabean ${ }^{4}$, Komilie \\ Situmorang ${ }^{5}$ \\ ${ }^{1}$ Universitas Pelita Harapan \\ ${ }^{5}$ Universitas Pelita Harapan
}

michael.recard@uph.edu, atalya.agustin@uph.edu, neng.priyanti@uph.edu, meicky.shoreamanis@uph.edu, komilie.situmorang@uph.edu

\begin{abstract}
Abstrak
Webinar dan workshop ini merupakan kelanjutan dari seminar dan workshop yang telah dilakukan sebelumnya. Sama seperti pada kegiatan sebelumnya, kegiatan ini dilaksanakan karena kebutuhan akan pengenalan dan pengintegrasian Teknologi Informasi dan Komunikasi (TIK) di dalam kelas dan di luar kelas bagi pengajar Bahasa Inggris. Kebutuhan akan pengenalan dan pengintegrasian ini didasari oleh bertujuan untuk menciptakan pengajaran yang interaktif, efektif dan menarik. Webinar ini dibagi menjadi 3 hari dengan total 8 pembicara dengan kisaran 80 peserta yang hadir di setiap sesi. Hasil yang dicapai pada peserta sudah memiliki kesadaran akan pentingnya penintegrasian teknologi dan pembelajaran Bahasa Inggris namun masih memerlukan pelatihan dalam hal-hal teknis yang sederhana; para peserta mendapatkan insight tentang proses belajar dan mengajar yang bermakna, mempertimbangkan konteks siswa dan guru, serta mengetahui signifikansi dari pembelajarannya sehingga peserta dapat merencanakan pembelajaran dengan lebih tepat sasaran dan efektif; dan terakhir para peserta mulai memahami pentingnya peran orang tua dan sekolah dalam Home-based learning yang bermakna serta kolaborasi antar pihak-pihak tersebut. Melihat keterlaksanaan kegiatan dan keterampilan para peserta yang dapat di maksimalisasi lagi dan wawasan yang perlu diperluas lagi, dipandang perlu untuk terus melanjutkan proses ini dalam bentuk penguatan kembali dan praktik yang lebih aplikatif untuk berbagai keterampilan berbahasa dan konteks.
\end{abstract}

Kata Kunci : Bahasa Inggris, Pembelajaran Jarak Jauh, Pembelajaran Bermakna, Workshop

\section{PENDAHULUAN}

Di Era Revolusi Industri 4.0, semua bidang kehidupan dihadapkan dengan fenomena disrupsi, yaitu penggantian sistem lama dengan sistem baru yang berbasis teknologi atau dikenal dengan Internet of Things (IOT) (Schwab, 2017). Kita bisa melihat contoh nyata dari menjamurnya toko online dan merupakan menjadi salah satu faktor toko offline dan mall tutup, peralihan penggunaan uang tunai digantikan dengan e-money dan $e$-wallet, pelanggan ojek pangkalan yang berpindah ke ojek online, dll. Perubahan ini secara otomatis mempengaruhi kondisi pembelajar, dalam konteks ini di tingkat SMA yang adalah Digital Natives. Digital Natives adalah mereka yang sejak lahirnya sudah dikelilingi dan juga menggunakan teknologi digital yang merujuk pada generasi $\mathrm{Z}$ dan Alpha (Kivunja, 2014). Kita bisa melihat bagaimana 
mereka (atau kita juga termasuk) tidak bisa lepas dari internet.

Menimbang dari fenomena disrupsi yang terjadi karena kemajuan teknologi di era Revolusi Industri 4.0, terdapat perubahan dalam metodologi pengajaran yang dilakukan guru kepada murid. Murid zaman ini yang merupakan generasi $\mathrm{Z}$ dalam mencari sumber materi untuk mengerjakan PR, mereka mengakses Google, dan tidak jarang mereka mengakses YouTube, Pinterest, Instagram, dsb.

Sebagai pendidik Kristen, perlu menindaklanjuti isu disrupsi agar peran dan pendekatan pedagogis secara kristiani dapat tetap bersinergi seiring kemajuan teknologi. Hal ini ditujukan agar pendidikan Kristen dapat sejalan dengan tujuan dan fungsi yakni untuk mengembalikan gambar dan rupa Allah serta rekonsiliasi bagi setiap siswa dengan Allah (Knight, 2009). Kita perlu menggarisbawahi pendidikan Kristen merupakan sebuah wadah dan upaya berkelanjutan secara sistematis untuk membawa siswa ke dalam pengenalan akan Allah dalam pengetahuan yang benar dengan membagikan pengetahuan, nilai-nilai, keterampilan, kepekaan, konsep-konsep dan kebiasaan yang konsisten dengan iman Kristen (Pazmino, 2010 \& Runtung, 2015).

Di samping itu, Mendikbud, Nadiem Makarim, dalam wawancaranya dengan awak media menjelaskan tentang pentingnya teknologi ketika dia ditunjuk Presiden Jokowi, "300 ribu sekolah dan 5 juta murid peran teknologi sangat besar di dalam kualitas efisiensi dan sistem administrasi pendidikan, jadi peran teknologi sangat penting, Saya belum bisa bilang terobosannya seperti apa, tapi yang jelas berhubung saya milenial dan background-nya teknologi, sudah pasti ada perubahan ke arah sana." (Prasetia, 2019).

Dampak era Revolusi Industri 4.0 yang telah merambah ke bidang pendidikan ini menjadi dasar pelaksanaan PkM ini dilaksanakan. Dengan kata lain, perubahan dari penggunaan sistem lama ke sistem baru yang berbasis teknologi memaksa semua orang, termasuk para guru untuk dapat menggunakannya selama kegiatan belajar mengajar di dalam dan luar kelas. Sementara itu, masih banyak guru yang merupakan digital immigrant yang berasal dari generasi baby boomers dan generasi X (Widiasworo, 2019). Di era Revolusi Industri 4.0 ini guru mau tidak mau akan menghadapi siswa yang sudah sangat akrab dengan penggunaan teknologi, serta siswa yang dapat belajar dengan lebih baik dengan lingkungan belajar yang berbasis teknologi (Ghavifekr \& Rosdy, 2015).

Selain itu PkM ini juga pada akhirnya adalah salah satu respons terhadap kejadian Pandemi COVID-19 yang mengakibatkan pembelajaran di semua level dilaksanakan secara online. Kebutuhan guru akan adanya strategi mengajar, media pembelajaran dan penilaian pembelajaran dalam konteks online yang begitu spesifik/khas di daerahnya masing-masing yang tentu saja melibatkan banyak pihak yaitu orang tua dan sekolah, membuat kegiatan ini semakin mendesak untuk dilakukan dan mengalami beberapa penyesuaian materi serta perubahan bentuk menjadi seminar dan workshop online.

Melihat urgensi dari pengintegrasian ini, maka seminar dan lokakarya "Penggunaan teknologi dalam pengajaran Bahasa Inggris di era Revolusi Industri 4.0" dilaksanakan bagi guru-guru Bahasa Inggris di sekitar UPH. PkM ini secara spesifik memilih guru-guru Bahasa Inggris sebagai sasaran peserta dikarenakan pentingnya Bahasa Inggris sebagai bahasa internasional yang pastinya diajarkan di setiap sekolah dan pendidikan Bahasa Inggris adalah bidang keilmuan semua pembicara atau penyelenggara $\mathrm{PkM}$.

Seminar dan workshop ini merupakan kegiatan lanjutan dari program PkM yang dilakukan oleh FIP- TC UPH (Fakultas Ilmu Pendidikan Teachers College Universitas Pelita Harapan) pada bulan Oktober 2019 dengan judul yang sama. Setelah melakukan kegiatan tersebut, terlihat dari evaluasi menggunakan Mentimeter pada tabel di bawah bahwa respons peserta cukup positif karena materi disampaikan dengan baik dan diskusi dapat berjalan dengan lancar sehingga kegiatan ini dapat meningkatkan dan memperluas wawasan dalam topik yang disajikan. Namun, terdapat juga hal yang dapat ditingkatkan yaitu mengenai alokasi waktu sesi dalam pelatihan. 
Evaluasi Umum Kegiatan

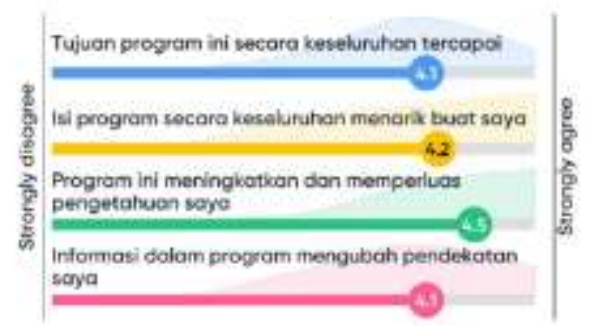

Gambar 1. Evaluasi Umum Kegiatan

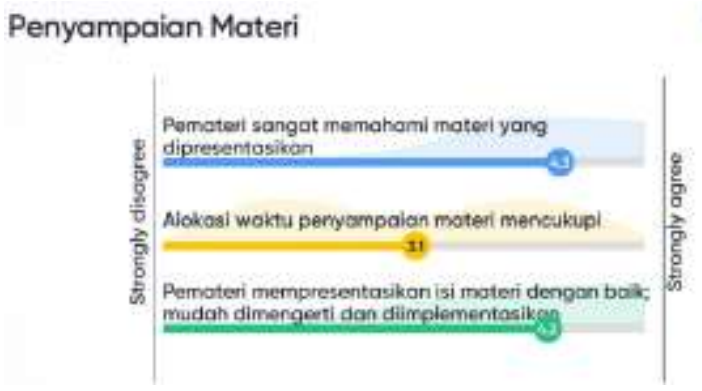

Gambar 2. Penyampaian Materi

Diskusi

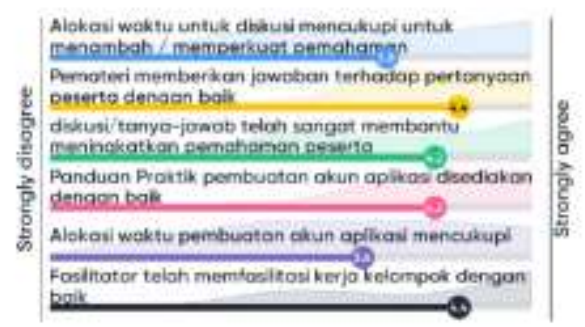

Gambar 3. Diskusi

Berdasarkan berbagai latar belakang yang disampaikan di atas, maka tim PkM melaksanakan kegiatan seminar dan workshop yang lebih komprehensif dan aplikatif.

Melihat tantangan-tantangan dan kendalakendala yang ada di lapangan serta hasil evaluasi pada kegiatan sebelumnya yang sudah disampaikan di atas, Prodi Pendidikan Bahasa Inggris FIP UPH dan mitra bersepakat untuk menentukan prioritas permasalahan yang akan diselesaikan. Terdapat beberapa permasalahan yang amat mendasar yang dapat ditarik dari permasalahan-permasalahan teknis di lapangan pada saat pelaksanaan seminar dan workshop sebelumnya. Permasalahanpermasalahan inilah yang akan diselesaikan selama pelaksanaan program PKM, yaitu: 1) Guru sudah memiliki kesadaran akan pentingnya penintegrasian teknologi dan pembelajaran sehingga dapat membuat pembelajaran menjadi lebih bermakna, efektif, dan efisien terutama di masa Pandemi dan Home-based learning, namun masih perlu pelatihan dalam hal-hal teknis misalnya strategi pengajaran, media, dan penilaian secara online sesuai dengan konteks masing-masing sampai menghasilkan luaran yang dapat langsung dipakai di dalam kelas; 2) Perlunya penekanan kembali kaitan antara kebutuhan siswa yang khas atau spesifik dalam konteks online dalam Pandemi ini, kebutuhan dan konteks guru, serta tujuan pembelajaran sehingga guru dapat merencanakan pembelajaran dengan lebih tepat sasaran dan efektif; 3) Perlunya penekanan pada pentingnya peran orang tua dan sekolah dalam Home-based learning yang bermakna.

\section{METODE}

Untuk menyelesaikan ketiga permasalahan mendasar tersebut di atas, terdapat beberapa solusi yang dapat ditawarkan dari pelaksanaan Webinar dan Workshop.

Pertama, para guru diberikan materi untuk memperluas wawasan tentang ICT serta Pembelajaran Bahasa Inggris jarak jauh yang bermakna. Terdapat beberapa sesi untuk menjabarkan topik ini yaitu: 1) Challenges faced by Parents and School; 2) School's Role in Preparing the New Normal Education; 3) Parents' role in guiding students; 4) Responding to Remote Learning: Teaching and Assessing Speaking in High and Low Context; 5) Teaching Writing from a Distance; 6) Workshop on Making Video for Language Teacher; 7) Creating Virtual Class using Edmodo; 8) English Language Distance Learning: a lesson from Ukraine

Kedua, para guru diberi kesempatan untuk memberikan komentar atau diskusi bersama dengan pembicara mengenai materi yang diberikan.

Terakhir, setelah sesi berlangsung, berkaitan dengan Teaching Writing dan Speaking, para peserta diminta untuk memberikan respons di dalam Flipgrid mengenai Pembelajaran Bahasa Inggris dan TIK yang selama ini dilakukan dan diminta untuk mengumpulkan tulisan sebagai respons dari materi ke dalam link yang sudah disiapkan. Hal ini sebagai bentuk role modeling dari 
para pembicara kepada para peserta sehingga para peserta dapat langsung mempraktekkan metode yang digunakan di dalam webinar dan workshop tersebut.

Berikut adalah tahapan atau langkahlangkah dalam melaksanakan solusi yang ditawarkan untuk mengatasi permasalahan yang sudah diuraikan di atas: 1) Ketua dan anggota PkM melakukan analisis kebutuhan terhadap para guru bersama dengan mitra PkM; 2) Ketua dan anggota PkM menentukan masalah yang akan ditindaklanjuti melalui pelaksanaan $\mathrm{PkM}$ ini; 3) Ketua dan anggota PkM menyusun topik pelatihan, menentukan jadwal, dan berkoordinasi dengan tim mahasiswa; 4) Ketua dan anggota PkM menyusun materi dan menyiapkan platform yang akan digunakan; 5) Ketua dan anggota PkM yang bertugas akan melaksanakan kegiatan secara online melalui Zoom sebagai pembicara dan host acara; 6) Pada tiap sesi, pembicara secara aktif memberikan materi dan berdiskusi dengan mahasiswa melalui sesi tanya jawab. Pembicara juga memberikan contoh pelaksanaan pembelajaran melalui platform yang digunakan; 7) Peserta diminta untuk berpartisipasi dalam Flipgrid setelah sesi Teaching Speaking dan mengumpulkan tulisan setelah sesi Teaching Writing; 8) Pada akhir setiap sesi, peserta diminta untuk mengisi lembar evaluasi melalui link yang nantinya akan dianalisis sebagai bahan dari evaluasi kegiatan; 9) Ketua dan anggota PkM akan memeriksa hasil kerja peserta dan memberi feedback; 10) Ketua dan anggota PkM akan menganalisis hasil evaluasi.

\section{HASIL DAN PEMBAHASAN}

\section{Pelaksanaan Kegiatan}

Melalui tabel berikut dipaparkan sesi-sesi Webinar dan Workshop yang dilaksanakan di dalam PkM ini:

Tabel 1. Jadwal Kegiatan Webinar

\begin{tabular}{|c|c|c|c|}
\hline No. & $\begin{array}{l}\text { Webinar dan } \\
\text { Workshop }\end{array}$ & Waktu & Pembicara \\
\hline \multicolumn{4}{|c|}{ Sesi 1} \\
\hline 1. & $\begin{array}{l}\text { Challenges faced by } \\
\text { Parents and School }\end{array}$ & $\begin{array}{l}\text { Jumat, } \\
17 \text { Juli }\end{array}$ & $\begin{array}{l}\text { Gunawan } \\
\text { Wibisono }\end{array}$ \\
\hline
\end{tabular}

(Parenthood and Homeschooling Enthusiast) Solidaritus (Education Practitioner) Juliana Tirza M. (Lecturer of Faculty of Liberal Arts UPH)

Sesi 2

Responding to Remote Learning:

1. Teaching and Assessing Speaking in High and Low Context 2. Teaching Writing
from a Distance

Sesi 3

Workshop on
1. Making Video for

Selasa, 21 Anjas Maradita

Juli 2020 (Professional

Video Creator

13.00- from

14.30 Purwalenta)

Keren

Watulingas

(Lecturer of

International

Teachers

College UPH)

English Language

3. Distance Learning:

a lesson from

Ukraine

Inna Ageikina

(Professional

Online Teacher)

Kegiatan yang semula dijadwalkan pada bulan Januari-Maret 2020 dan dibawakan dalam bentuk tatap muka di UPH seperti yang dilaksanakan pada seminar dan workshop bagian pertama pada bulan Oktober 2019, dilaksanakan pada Bulan Juli 2020 dan disesuaikan materi dan bentuknya menjadi tatap maya (online) melalui Zoom. Hal ini dikarenakan Pandemi Covid yang berdampak pada kebijakan Working from Home dan Home-based Learning.

Pendidikan 702 
Kegiatan Webinar dan Workshop ini membahas topik-topik seputar pembelajaran online dalam keadaan Pandemi COVID-19 dan persiapan New Normal di sekolah dan di rumah. Selain itu Workshop pun dikemas dengan lebih aplikatif sehingga menjadi contoh yang praktis bagi peserta untuk dapat mencoba metode, media, dan asesmen di dalam mata pelajaran Bahasa Inggris khususnya Teaching Speaking dan Teaching Writing.

\section{Evaluasi Kegiatan}

Berdasarkan pelaksanaan kegiatan yang sudah disampaikan di atas, berikut adalah evaluasi dari setiap sesi oleh para peserta serta luaran yang dihasilkan oleh para peserta. Para peserta mengisi 3 link yang berbeda untuk mengevaluasi 3 sesi dalam Webinar dan Workshop ini. Pada evaluasi sesi pertama, terdapat beberapa pertanyaan yang diajukan dalam evaluasi ini yaitu: 1) Info tentang acara ini didapatkan dari mana? 2) Hal baru yang didapat dalam webinar ini? 3) Masukan topik untuk dibahas pada seminar yang akan datang? 4) Masukan untuk panitia terkait pelaksanaan webinar.

Respons dari peserta yang menyatakan tentang informasi acara ini dijelaskan di dalam Pie Chart berikut.

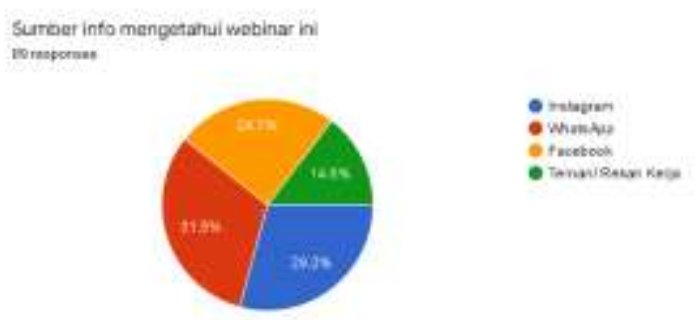

Diagram 1. Sumber Informasi Seminar

Berdasarkan diagram tersebut sebagian besar peserta mendapatkan info Webinar ini dari Whatsapp $(31,5 \%)$ atau sekitar 28 orang dari 89. Sementara itu sebagian kecil peserta yaitu $14.6 \%$ atau sebanyak 13 peserta mendapatkan info dari rekan kerja.

Berkaitan dengan hal baru dalam webinar yang didapatkan oleh peserta, dapat disimpulkan bahwa paling banyak peserta mendapatkan hal baru mengenai penggunaan platform sederhana dalam masa distance learning misalnya Facebook, pengetahuan dan tips dalam masa Pandemi bagi orang tua, misalnya dalam hal platform ramah anak, pendampingan psikologi bagi remaja dalam era belajar dari rumah, peran orang tua dalam distance learning, peran orang tua bekerja dan mendampingi anak di rumah, dan blended learning.

Berkaitan dengan masukan peserta tentang topik pada seminar yang akan datang, terdapat beberapa topik yaitu penerjemahan, pendidikan online bagi anak berkebutuhan khusus, membatasi pemberian gadget pada anak, Critical Thinking, pendidikan karakter, perilaku berbahasa di masa pandemi, penggunaan WhatsApp, Instagram, Zoom, and Google Meet, learner's autonomy, dan game.

Terkait pelaksanaan webinar dan workshop, para peserta menyampaikan bahwa secara umum program ini sudah berjalan dengan baik dan profesional, para pembicara menyampaikan materi dengan baik dan aplikatif, serta panitia juga cepat tanggap dengan adanya persoalan teknis. Namun demikian, ada beberapa hal yang dapat ditingkatkan yaitu penambahan waktu agar lebih panjang dan pemilihan waktu yang lebih baik, misalnya lebih pagi atau memberi kesempatan kepada yang beribadah serta pertimbangan untuk menggunakan platform lain karena ada beberapa yang bermasalah pada saat join meeting.

Pada evaluasi sesi kedua, terdapat beberapa pertanyaan yang diajukan dalam evaluasi ini yaitu: 1) Apakah konten webinar ini relevan dengan pekerjaan anda? 2) Apakah konten webinar ini mudah dipahami? 3) Apakah fasilitator webinar ini memiliki pemahaman yang baik terhadap konten yang disampaikan? 4) Apakah menurut anda fasilitator mempersiapkan materi dengan baik? 5) Hal baru yang didapat dalam webinar ini? 6) Masukan topik untuk dibahas pada seminar yang akan datang? 7) Masukan untuk panitia terkait pelaksanaan webinar.

Respons peserta terhadap pertanyaanpertanyaan di atas tergambar dalam diagram dan paparan berikut. 


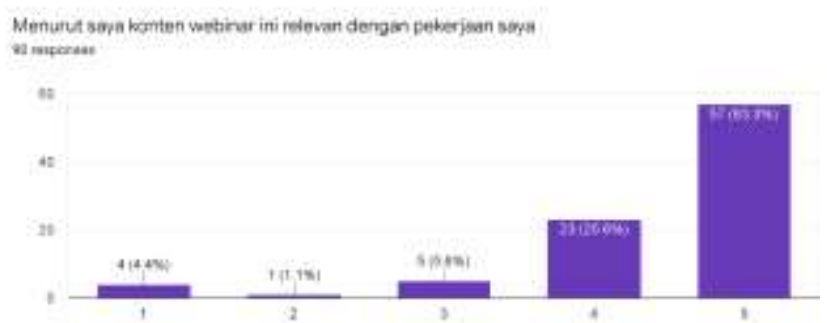

Diagram 2. Relevansi Konten Webinar dengan Pekerjaan

Dari diagram di atas dapat disimpulkan bahwa sebanyak 57 dari 90 peserta atau $63.3 \%$ menyatakan bahwa konten sangat srelevan dengan pekerjaan mereka. Hal ini disebabkan karena profesi para peserta adalah guru bahasa Inggris.

Sementara itu, respons peserta tentang konten webinar dijelaskan di dalam diagram dan paparan berikut.

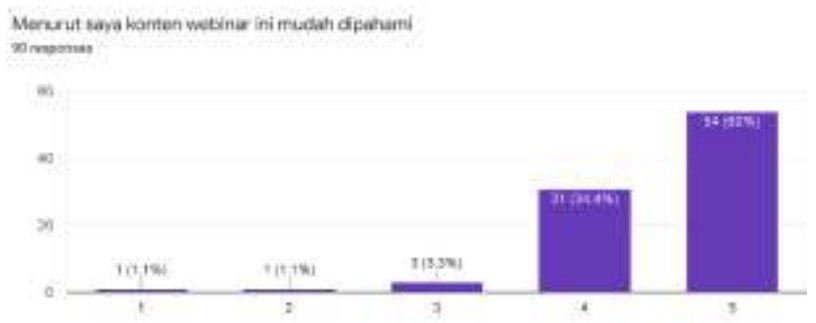

Diagram 3. Konten Webinar

Berdasarkan diagram di atas, $60 \%$ peserta atau 54 orang dari 90 peserta menyatakan bahwa konten webinar sangat mudah dipahami. Hal ini tentu saja berkaitan dengan ksemampuan pembicara untuk menyampaikan materi dengan sederhana namun aplikatif.

Selanjutnya berikut dipaparkan mengenai respons peserta tentang kemampuan pembicara untuk menyampaikan materi.

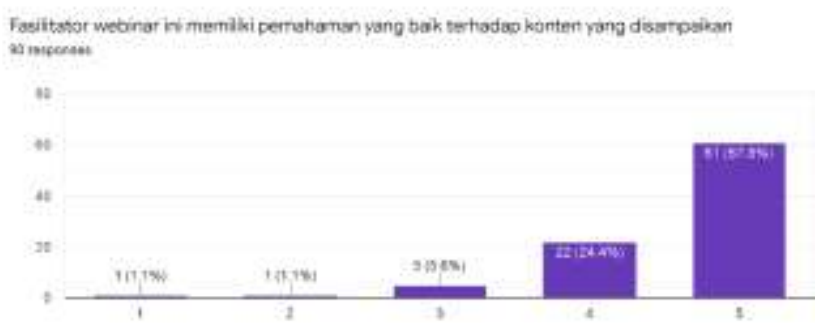

Diagram 4. Pemahaman Fasilitator dan Konten Webinar

Dari diagram di atas dapat disimpulkan bahwa 61 orang atau $67,8 \%$ peserta menyatakan bahwa pembicara memiliki pemahaman yang baik terhadap konten yang disampaikan. Pembicara merupakan para profesional di bidangnya masing-masing yang sudah mempraktikkan penggunaan teknologi di kelas dan mengevaluasinya.

Paparan berikut mengenai persiapan materi oleh pembicara. Diagram yang menggambarkannya adalah sebagai berikut.

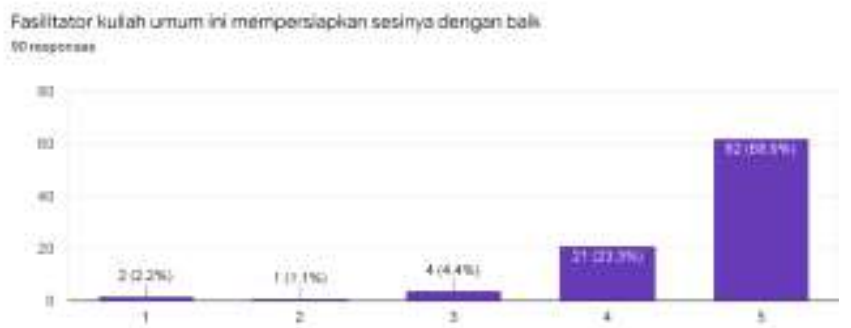

Diagram 5. Persiapan Fasilitator

Sebanyak $68.9 \%$ atau 62 orang dari 90 orang berpendapat bahwa para pembicara mempersiapkan sesinya dengan sangat baik. Hal ini sejalan dengan penyampaian materi yang juga disampaikan dengan baik.

Melalui evaluasi ini dapat disimpulkan pula bahwa ada beberapa hal baru yang didapat oleh para peserta yaitu cara menjadi guru yang profesional melalui penggunaan aplikasi yang efektif misalnya Flipgrid. Selain itu para peserta juga mendapatkan perspektif baru mengenai mengajar Speaking dan 
Writing secara online. Para peserta juga memberikan masukan mengenai topik apa yang akan dibahas pada webinar yang akan datang yaitu "How to be a smart teacher than technology", Using Edmodo, Assessment in Language Learning, Teaching Listening, and Teaching Pronunciation. Sebagian besar topik adalah mengenai integrasi teknologi dan pembelajaran Bahasa Inggris. Sementara itu mengenai masukan untuk panitia terkait pelaksanaan webinar yaitu berkaitan dengan pemilihan waktu pelaksanaan yang lebih efektif misalnya weekend serta masalah teknis pada saat peserta akan masuk ke dalam meeting. Peserta juga mengapresiasi cara kerja panitia yang dinilai sudah cukup baik dan profesional.

Pada evaluasi sesi ketiga, terdapat beberapa pertanyaan yang diajukan dalam evaluasi ini yaitu: 1) Apakah konten webinar ini relevan dengan pekerjaan anda? 2) Apakah konten webinar ini mudah dipahami? 3) Apakah fasilitator webinar ini memiliki pemahaman yang baik terhadap konten yang disampaikan? 4) Apakah menurut anda fasilitator mempersiapkan materi dengan baik? 5) Hal baru yang didapat dalam webinar ini? 6) Masukan topik untuk dibahas pada seminar yang akan datang? 7) Masukan untuk panitia terkait pelaksanaan webinar.

Pada paparan berikut ini akan dijelaskan respons peserta terhadap pertanyaan-pertanyaan di atas.

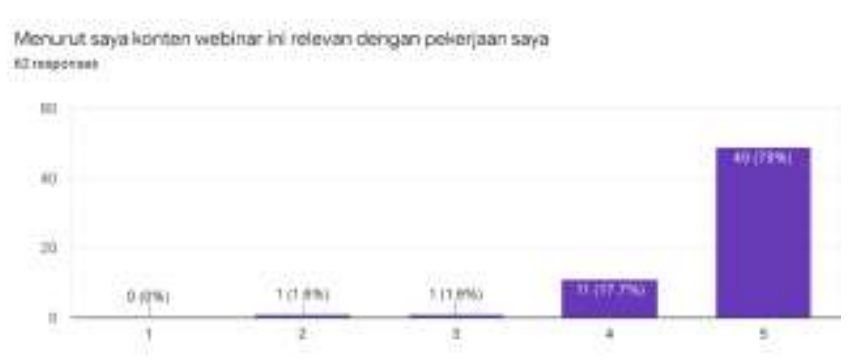

\section{Diagram 6. Relevansi Konten Webinar dengan} Pekerjaan

Dari diagram di atas terlihat bahwa sebanyak 49 dari 62 responden atau sebanyak $79 \%$ menyatakan bahwa konten Webinar relevan dengan pekerjaan. Hal ini dikarenakan sebagian besar peserta adalah guru Bahasa Inggris dan juga sebagai orang tua serta terlibat dengan administrasi sekolah yang membutuhkan wawasan terhadap online learning di masa Pandemi.

Sementara itu berikut respons peserta terhadap Konten webinar.

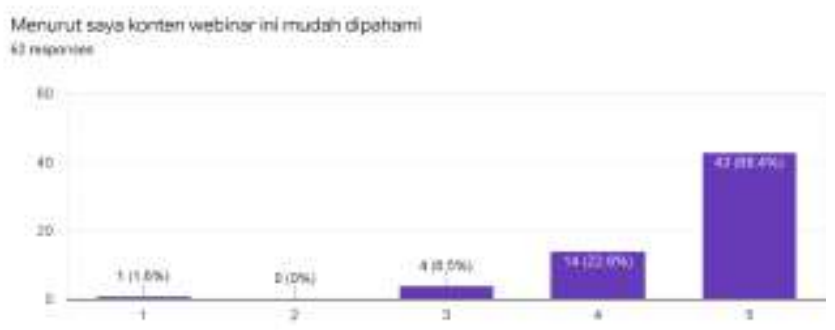

Diagram 7. Konten Webinar

Dari diagram tersebut dapat disimpulkan bahwa sebanyak 43 dari 62 responden atau sebesar 69,4\% peserta menyatakan bahwa konten Webinar mudah dipahami. Hal ini sejalan dengan pendapat peserta bahwa penyampaian konten oleh para pembicara dilaksanakan dengan baik sehingga konten mudah dipahami.

Selain itu untuk pertanyaan ketiga, diagram yang menggambarkan responspeserta dipaparkan di bawah ini.

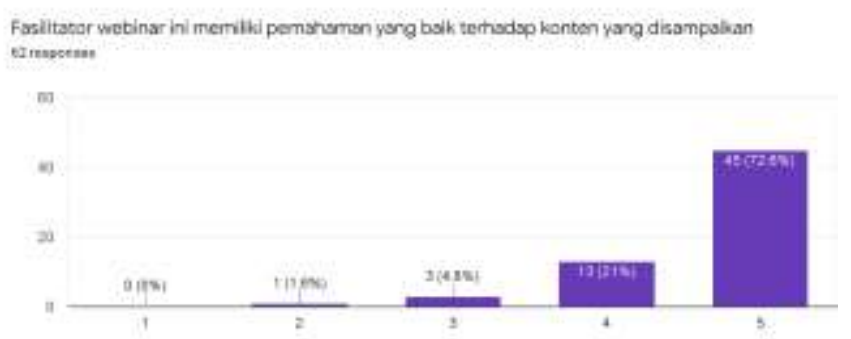

Diagram 8. Pemahaman Fasilitator dan Konten Webinar

Berdasarkan diagram di atas, sebanyak 45 dari 62 peserta atau $72.6 \%$ menyatakan bahwa Webinar memiliki pemahaman yang baik terhadap konten 
yang disampaikan. Hal ini berarti seluruh pembicara adalah para profesional pada bidangnya masingmasing.

Diagram terakhir adalah mengenai respons peserta tentang kesiapan pembicara.

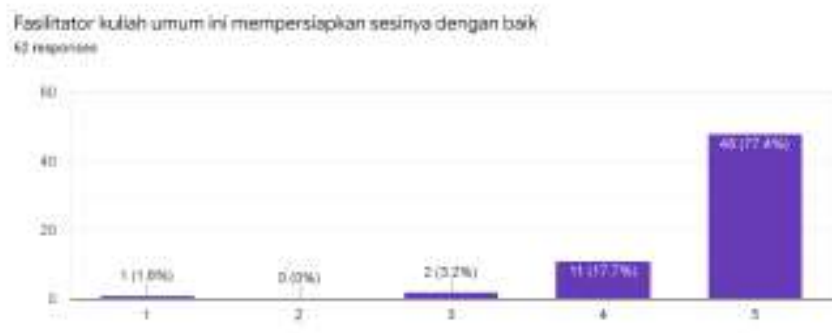

Diagram 9. Persiapan Fasilitator

Sebanyak 48 peserta atau $77.4 \%$ menyatakan bahwa Fasilitator mempersiapkan sesi dengan baik. Hal ini sejalan dengan pendapat para peserta bahwa fasilitator menguasai bidang yang dibawakan sehingga dapat mempersiapkan sesi dengan baik.

Melalui evaluasi ini juga dapat disimpulkan pula bahwa ada beberapa hal baru yang didapat oleh para peserta yaitu perspektif baru mengenai aplikasi yang dapat digunakan dalam mengajar, bagaimana membuat video, dan menggunakan Edmodo. Para peserta juga memberikan masukan mengenai topik apa yang akan dibahas pada webinar yang akan datang yaitu student's autonomy in learning, authentic assessment, collaboration in teaching online, Zoom for teaching and Google Meet, membuat video animasi, dan TOEFL. Sebagian besar topik adalah mengenai integrasi teknologi dan pembelajaran Bahasa Inggris. Sementara itu mengenai masukan untuk panitia terkait pelaksanaan webinar yaitu berkaitan dengan pemilihan waktu pelaksanaan yang lebih efektif dan lebih panjang serta mempertimbangkan pengumpulan beberapa tugas di waktu yang sama karena tidak efektif. Peserta juga mengapresiasi acara yang berjalan baik dan konten serta pembicara yang baik.

\section{Luaran yang Dihasilkan Peserta}

Terdapat luaran yang dihasilkan oleh para peserta melalui sesi "Responding to Remote Learning: Teaching and Assessing Speaking in High and Low Context" yaitu partisipasi pada Flipgrid. Setelah pembicara memberikan contoh penggunaan Flipgrid untuk mengajar keterampilan berbicara (speaking), para peserta diminta untuk mengekspresikan pendapatnya dengan cara berpartisipasi melalui platform tersebut. Peserta diminta menjawab beberapa pertanyaan yaitu: "Technology has done some much to our teaching during this pandemic. What kind of technologies/apps have you used to teach during this pandemic and why and what are your biggest challenges and how do you cope with them?". Terdapat 47 peserta yang mengirimkan respons dalam Flipgrid yaitu 43 guru dan 4 mahasiswa.

Respons yang diberikan oleh sebagian besar para peserta yaitu menggunakan Facebook dan Whatsapp Group sebagai media mengajar namun hanya untuk mengirimkan tugas yang harus dikerjakan dan bukan untuk diskusi interaktif. Respons pertanyaan kedua adalah tantangan mengenai keadaan sosial ekonomi siswa yang kurang mampu membeli paket data serta wilayah geografis yang kurang mendukung. Respons para peserta terlihat dalam gambar di bawah ini.

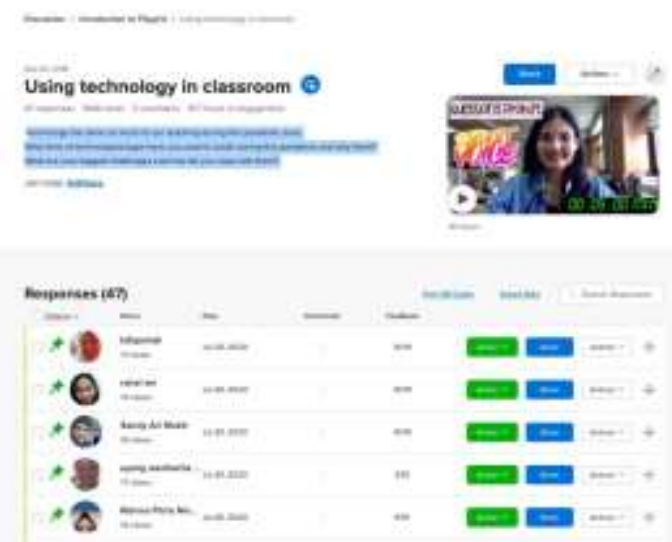

Gambar 4. Partisipasi Peserta dalam Flipgrid 


\section{KESIMPULAN}

Terdapat tiga hal yang menjadi simpulan dari kegiatan ini yaitu: 1) Guru sudah memiliki kesadaran akan pentingnya penintegrasian teknologi dan pembelajaran Bahasa Inggris namun masih memerlukan pelatihan dalam hal-hal teknis yang sederhana misalnya strategi pengajaran, media, dan penilaian secara online sesuai dengan konteks masing-masing serta forum untuk bertukar pikiran atau membagikan hasil inovasinya di dalam kelas; 2) Para peserta mendapatkan insight tentang proses belajar dan mengajar yang bermakna, mempertimbangkan konteks siswa dan guru, serta mengetahui signifikansi dari pembelajarannya sehingga guru dapat merencanakan pembelajaran dengan lebih tepat sasaran dan efektif; 3) Para guru mulai memahami pentingnya peran orang tua dan sekolah dalam Home-based learning yang bermakna serta kolaborasi antar pihak-pihak tersebut.

Melihat keterlaksanaan kegiatan dan keterampilan para guru yang dapat dimaksimalisasi lagi dan wawasan yang perlu diperluas lagi, dipandang perlu untuk terus melanjutkan proses ini dalam bentuk penguatan kembali dan praktik yang lebih aplikatif untuk berbagai keterampilan berbahasa dan konteks. Para guru juga harus lebih banyak diberikan kesempatan untuk mengeksplorasi berbagai aplikasi mengajar untuk pembelajaran bahasa secara jarak jauh.

\section{UCAPAN TERIMAKASIH}

Kami berterima kasih kepada Lembaga Penelitian dan Pengabdian kepada Masyarakat Universitas Pelita Harapan (LPPM UPH) yang telah membantu

mendanai

Pengabdian

kepada

Masyarakat dan penulisan artikel ini dengan nomor kontrak 156/LPPM-UPH/I/2020.

\section{REFERENSI}

Apriliyadi. (2019, January 30). kemdikbud. Retrieved from psmk.kemdikbud.go.id: https://psmk.kemdikbud.go.id/konten/4144/hadapirevolusi-industri-40-smk-wajib-kuasai-bahasaasing-dan-teknologi

Ghavifekr, S., \& Rosdy, W. A. W. (2015). Teaching and Learning with Technology: Effectiveness of ICT Integration in Schools. International Journal of Research in Education and Science, 1(2), 175-191. https://doi.org/10.21890/ijres.23596

Kepala Bidang Guru dan Tenaga Kependidikan (GTK) Dinas Pendidikan Jawa Barat. (2018, 12 20). Guru Harus Menginspirasi di Era Revolusi Industri 4.0. (Y. E. HARUSUSILO, Interviewer)

Prasetia. (2019, 10 23). Visi Teknologi Nadiem Makarim untuk Dunia Pendidikan Indonesia. Retrieved from Detik.com: https://inet.detik.com/law-and-policy/d4756880/visi-teknologi-nadiem-makarim-untukdunia-pendidikan-indonesia

Schwab, K. (2017). The fourth industrial revolution. Geneva: World Economic Forum.

Widiasworo, E. (2019). Guru ideal di era digital: Panduan pemanfaatan teknologi untuk guru masa kini (1st ed.). Yogyakarta: Noktah. 